\title{
CURRENT TRENDS AND PERSPECTIVES IN TYRE INDUSTRY
}

\author{
Nicoleta Chicu* \\ Bucharest University of Economic Studies, Romania \\ E-mail: chicu_nicoleta@yahoo.com
}

\section{Adina-Liliana Prioteasa}

Bucharest University of Economic Studies, Romania

E-mail: prioteasaadina@gmail.com

\author{
Alecxandrina Deaconu \\ Bucharest University of economic Studies, Romania \\ E-mail: alecxandrinadeaconu@gmail.com
}

(Received: February 2020: Accepted: April 2020; Published: June 2020)

\begin{abstract}
The digital age or the 4.0 industry makes its presence felt in all areas of the economy, making serious contributions to its development. The automotive industry is in a phase of change, acting on all its sub-industries such as the automotive tyre industry. We are witnessing a process in which large companies no longer sell a simple car or basic tyres, but resort to new technologies and digitalization to sell complex services tailored to the needs of consumers. Terms such as connectivity, mobility, autonomy became the main pillars in the development of such solutions integrated in the current market. Based on a SWOT analysis and a focus group organized with specialists from the field, this article aims to highlight the tyre industry market, which are the latest trends in the technologies used for development of the tyre industry, which are the factors that contribute to its growth and which are the threats, the opportunities for the big competitors in the market: Bridgestone, Goodyear, Michelin and Pirelli.
\end{abstract}

Keywords: tyre manufacturing industry, digitalization, innovation, autonomous, trends.

JEL Codes: L11, L62, O14, O31, Q55

\footnotetext{
*Corresponding author: Nicoleta Chicu. E-mail: chicu_nicoleta@yahoo.com

Copyright (C) 2020 The Author(s). Published by VGWU Press

This is an Open Access article distributed under the terms of the Creative Commons BY 4.0 license (Creative Commons - Attribution 4.0 International - CC BY 4.0) which permits unrestricted use, distribution, and reproduction in any medium, provided the original author and source are credited.
}

36 sciendo Studia Universitatis "Vasile Goldis" Arad. Economics Series Vol 30 Special Issue 2/2020 ISSN: 1584-2339; (online) ISSN: $2285-3065$ 
Chicu, N., Prioteasa, A.L., Deaconu, A., (2020)

Current trends and perspectives in tyre industry

\section{Introduction}

The tyre industry is now characterized as a volatile one, being closely linked to the production of automobiles, but also to other factors such as raw materials, their availability and their unstable prices. The companies currently present in the industry have not only financial and production challenges, but they struggle with the strong wave of new competitors from Asia, respectively China. The importance of this field is outlined by the objectives of this industry, the latest generation of technologies that are used and the realization of the production processes of the car tyres. Thus, the new technology and the innovation play an important role for the entire automotive industry forcing the companies to rethink business models (Gao, Kaas, Mohr \& Wee, 2016). All these aspects have been developed in literature review, pointing out their importance.

In this sense, this article has an empirical research that shows the current trends in the industry and the main market competitors and how they act on the market by using new technologies and digitalization and the changes that occur while adopting new technologies which means an adaptation effort, additional costs. However, we tried to figure out the following question in research:

RQ1: Which are the main trends that influence the business activity of the main players in the automotive tyre industry?

RQ2: Which are the main factors that will increase the production of the tyre industry?

RQ3: In a volatile economic context, which are the main strengths, weaknesses, opportunities and threats that the 4 main players in the tyre industry have nowadays?

\section{Literature review}

\subsection{An overview of nowadays tyre industry}

In the Annual report from European Tyre \& Rubber Manufacturers Association (ETRMA), President Christian Kotz described the rubber and tyre industry not only by a simple innovation, but by one that cares about the environment in which it functions, for the people they work for and for those who are also doing their jobs and contribute to a sustainable future. The rubber tyre and tyre industry are present in our everyday life, being there at every step of the road and also influencing our lives and our world, with a focus on safety and sustainability.

Peter Drucker, the father of management thinking, describes the automotive industry as "the industry of industries", stressing its importance in the economy. Even today, this industry continues to have the largest production activity, reaching 5 times more output each year. As with any manufacturing industry, the automotive 
Chicu, N., Prioteasa, A.L., Deaconu, A., (2020)

Current trends and perspectives in tyre industry

industry needs to purchase the various components that are needed for assembling cars, including sophisticated equipment and sub-assemblies. Therefore, in the daily running of cars, this means necessary consumables such as: fuel, car tyres, spare parts, tubes, etc.

The actual automotive industry is more advanced than it was 10 years ago both in Europe and Romania and this is due to the phenomenon of polarization of the markets and the modification of the production chains. Even though the activities of the factories have changed, Romania is recognized as having cheap labour, the big companies being directly interested in outsourcing their services in our country and investing directly in them (Guga, 2018).

The phenomenon of globalization brings a significant growth in the automotive industry but in the same time, it draws attention to the gap between traditional business processes (design, manufacturing, logistics, sales) and information technologies and process optimization. In this context, upgraded technology affected the automotive industry, forcing the companies to rethink the provided services and products (Svahn, Mathiassen, \& Lindgren, 2017). Thus, the current focus is on the future, imposing new concepts and digital transformations of the processes existing in companies. Today's automotive industry presents the following objectives:

- The needs of the customers and the market for the products related to the industry are in a continuous flow of change, causing the increase of cost, but also of the complexity of the production processes;

- Integrating production and logistics as best as possible in the context of decreasing product life cycle;

- Maintenance costs regarding IT for the old systems generate constantly increasing, unnecessary costs;

- Rethinking the planning, implementation and control processes so that they turn into "digital factories", based on the latest technological equipment;

- Increasing investments at electronic level by developing or buying software applications that support the comfort and safety of customers.

Guga (2018) argues that the entire industry will change, based on the emergence of electric motors, autonomous technology, connectivity, but also due to the emergence of digitization in the production process. Moreover, he argues that the Romanian automotive industry must overcome the low-cost paradigm and make room for the new industry. This aspect is also supported by a PWC report (2018) on trends in the transformation of the automotive industry, which highlights a model called "ESCY" (electrified, autonomous, shared, connected, yearly updated) which contains 5 key elements: electric cars, autonomy, use of shared cars, their connection with various technologies and permanent update. The same approach

38 Sciendo Studia Universitatis "Vasile Goldis" Arad. Economics Series Vol 30 Special Issue 2/2020 ISSN: 1584-2339; (online) ISSN: $2285-3065$

Web: publicatii.uvvg.ro/index.php/studiaeconomia. Pages $36-56$ 
Chicu, N., Prioteasa, A.L., Deaconu, A., (2020)

Current trends and perspectives in tyre industry

was outlined by Cohen \& Kietzmann (2014) adding the idea of e-mobility and mobility-on-demand using autonomous driving.

The ETRMA report (2016-2017) reveals that the rubber and tyre industry's efforts are headed in two directions: one for protecting the environment, by reducing $\mathrm{CO}_{2}$ emissions, while improving tyre safety and maintaining the industry's competitiveness so that the second one is towards tyre connectivity with the emerging technology.

Stoian (2015) outlined that the tyre industry is closely related to the car construction industry, having a direct impact on the number of tyres produced for new cars, but also on the related services belonging to the car services (tyre change, re-sell). Because of this, the tyre market can suffer changes in terms of demand and volumes. According to Michelin's 2017 annual report, the automotive tyre market has been valued at $\$ 150$ billion, growing since 2015. Moreover, the global tyre industry is divided between Bridgestone (14.6\%), Michelin (14\%), Goodyear (9\%), other tyre manufacturers (less than $2 \%$ of the market) - $34.1 \%$ and average car tyre manufacturers (2-7\% of the market) - 28.2\% (Michelin, 2017) (Fig. 1). Compared to 2015, this market had small changes for Goodyear - a decrease of $0.2 \%$ in the market compared to 2016 and for Bridgestone - a decrease of $0.4 \%$. The company that had a small growth on the market was Michelin, registering $0.2 \%$ more than in 2015 (Michelin, 2017) (Fig. 2).

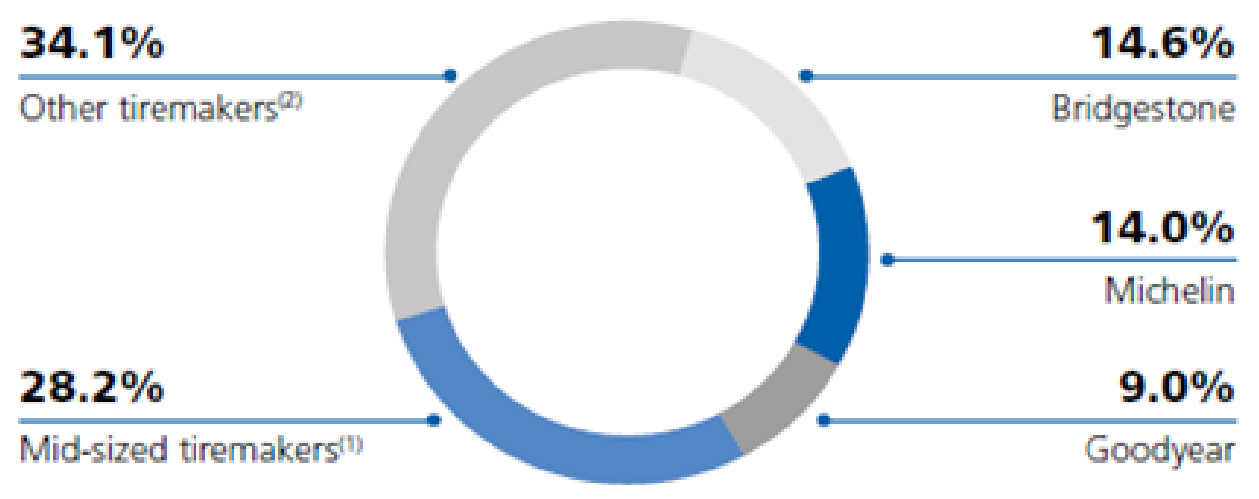

Figure 1 Global car tyre market 2016

Source: Michelin's 2017 Annual Report, p. 72 


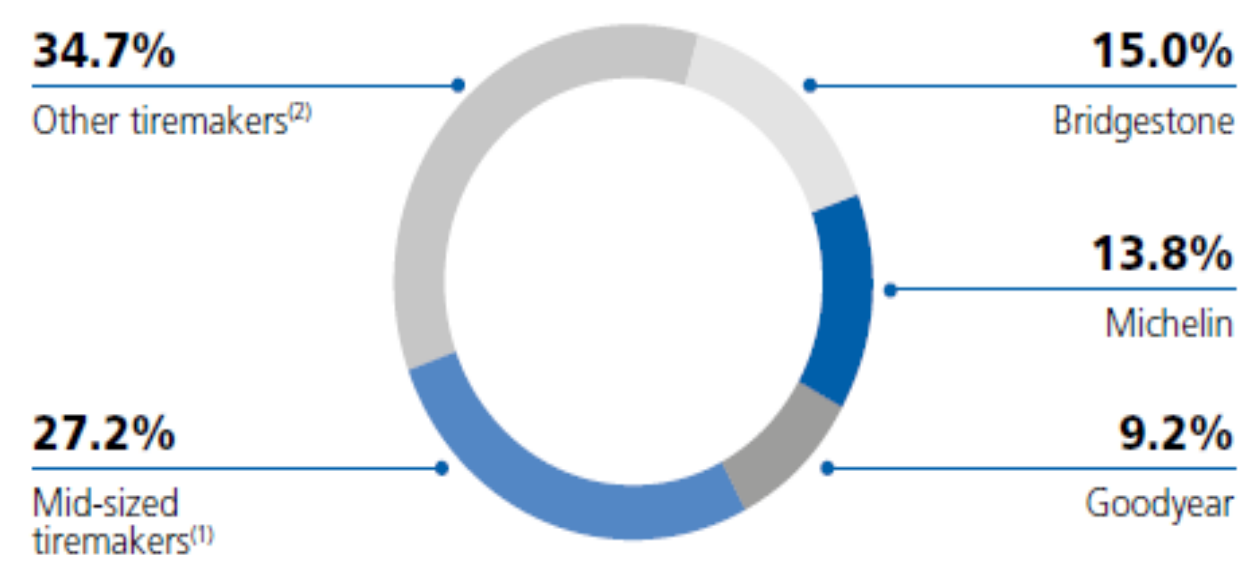

Figure 2 Global car tyre market 2015

Source: Michelin's 2017 Annual Report, p. 72

Stoian (2015) draws attention to the production of car tyres, which is determined by a number of factors such as:

- Instability of prices for raw materials but also for utilities entering the production process, including steel, natural gas and oil;

- Business development worldwide and improving economic conditions;

- Introducing new tariffs or modifying current customs ones, including antidumping and countervailing tariffs for imported tyres from China or the US;

- Instability of capital and financial markets.

For example, in Romania, another factor in increasing the volume of tyres was the introduction of the mandatory winter tyres in 2011. According to GO 5/2011 and the Law 161/2011, drivers must have their cars equipped with winter tyres when driving on public roads covered by snow or ice. At European level, there are regulations regarding the countries that have introduced this law - 16 countries require winter tyres according to a specialized site Oponeo.co.uk.

Worldwide, the first 6 market competitors are spread geographically throughout the world, with factories and active presence in most countries in Europe, but also in other continents (Table 1). According to this table, it can be observed that the car tyre market is distributed / present in many countries, which automatically generates sales, but also an interest in this industry. 
Chicu, N., Prioteasa, A.L., Deaconu, A., (2020)

Current trends and perspectives in tyre industry

\begin{tabular}{|c|c|c|c|c|}
\hline \multicolumn{5}{|c|}{ Table 1 The main manufacturers of car tyres } \\
\hline No. & Company & $\begin{array}{c}\text { Country of } \\
\text { origin }\end{array}$ & $\begin{array}{c}\text { Presence in the } \\
\text { world (no of } \\
\text { coutries) }\end{array}$ & No. of factories \\
\hline 1. & Bridgestone & Japan & $>150$ & $>180$ \\
\hline 2. & Michelin & France & 170 & 69 \\
\hline 3. & Goodyear & USA & 54 & 49 \\
\hline 4. & Pirelli & Italy & 160 & 19 \\
\hline 5. & Continental & Germany & 56 & 13 \\
\hline 6. & Hankook & South Koreea & $>180$ & 5 \\
\hline
\end{tabular}

Source: author's self-processing based on information from Bridgestone, (2019); Michelin,

(2020); Goodyear, (2019); Pirelli, (2019); Continental, (2020); Hankook, (2020);

World Tyre Manufacturers - Market Analysis - 2010-2015 Trends - Corporate Strategies (2010) points out the industry leaders which are found in different geographical areas, with larger or smaller market shares, as it is shown in Table 2:

Table 2 The presence of leaders at geographical level

\begin{tabular}{|c|c|c|c|c|c|}
\hline Company & Europe & $\begin{array}{c}\text { North } \\
\text { America }\end{array}$ & $\begin{array}{c}\text { Latin } \\
\text { America }\end{array}$ & $\begin{array}{c}\text { Asia- } \\
\text { Pacific }\end{array}$ & $\begin{array}{c}\text { Africa \& } \\
\text { Middle East }\end{array}$ \\
\hline Bridgestone & ++ & ++ & ++ & ++ & ++ \\
\hline Michelin & ++ & ++ & ++ & ++ & + \\
\hline Goodyear & ++ & ++ & + & ++ & + \\
\hline Continental & ++ & + & + & + & + \\
\hline Pirelli & ++ & + & ++ & + & + \\
\hline Hankook & + & + & + & + & \\
\hline
\end{tabular}

Source: author's self-processing based on World Tyre Manufacturers - Market Analysis 2010-2015 Trends - Corporate Strategies (2010)

+++ predominant presence; ++ important presence; + marginal presence

\subsection{Technology}

At a technological level, each company tries to bring forward new technologies or innovations in the field of car tyres industry, but also of adjacent services. If we look back in the past, tyres did not have such a high rolling capacity; today, they reach 50 thousand kilometres compared to 35 thousand previously. In terms of weight, we can see a decrease, reaching an average of $8 \mathrm{~kg} /$ tyre today compared to $11.6 \mathrm{~kg}$ in the past; their rolling resistance decreased, falling down to 0.9 compared 
Chicu, N., Prioteasa, A.L., Deaconu, A., (2020)

Current trends and perspectives in tyre industry

to 1.3. Moreover, we can see the progress in safety: the breaking distance on dry surface decreased from $56 \mathrm{~m}$ to $36 \mathrm{~m}$; the breaking distance on wet surface decreased from $85 \mathrm{~m}$ to $65 \mathrm{~m}$, the maximum permissible speed reached $300 \mathrm{~km} / \mathrm{h}$ compared to $200 \mathrm{~km} / \mathrm{h}$ according to specialized site.

The evolution of the market has forced big companies to also turn their attention to the services of the industry: the monitoring of the tyres by sensors, the transmission of driving data of the drivers in storage databases and also, solutions for the reduction of fuel consumption and the adaptation of speed, according to the environment.

In order to have an overview of the latest technologies developed in the tyre industry, we have chosen to present the technological innovations of the first four competitors of the industry: Bridgestone, Michelin, Goodyear and Pirelli.

According to the official web site of Bridgestone and some specialized tyre websites, the company has inovated this field as it follows:

- Enliten technology - is known in the market as the range of "light" tyres due to the reduced quantity of used materials. It is noted that this type of tyre has satisfactory results regarding the reduction of fuel consumption, having a rolling resistance by $20 \%$ lower than the standard tyres.

- Ecological Utopia technology (Ecopia) - as the name suggests, Ecopia tyres are environmentally friendly. These have had good results, leading to a reduction in carbon dioxide emission and fuel consumption, as well as rolling resistance.

- Drive guard technology - is a type of tyre that is based on the idea of running flat (it can still work even if the tyre had perforations or cuts with a maximum speed of $80 \mathrm{~km} / \mathrm{h}$ ). Unlike other tyres, it can be fitted on to all cars that have Tyre-Pressure monitoring system (TPMS).

Moreover, the company proposes the following types of technologies: Airless technology, Ologic technology and Sensing technology.

Michelin suggests new technologies for the automotive tyre industry, proposing serious contributions for their development and integration at the end-user level (Michelin, 2019):

- Radial technology - used mainly for agricultural vehicles, this technology has brought a big plus in the tyre industry. This type of tyre has registered significant reductions in fuel, but it has also contributed actively to reducing shocks and the impact to shocks and also unevenness.

- Uptis technology - developed together with General Motors, the Uptis (unique puncture-proof Tyre System) tyre is the dream of any driver - it doesn't need air and will never bother you. The proposed technology consists of replacing the air chamber with a structure made of special

42 Sciendo Studia Universitatis "Vasile Goldis" Arad. Economics Series Vol 30 Special Issue 2/2020 ISSN: 1584-2339; (online) ISSN: $2285-3065$

Web: publicatii.uvvg.ro/index.php/studiaeconomia. Pages $36-56$ 
Chicu, N., Prioteasa, A.L., Deaconu, A., (2020)

Current trends and perspectives in tyre industry

materials (composites). The structure is capable of taking all shocks and unevenness of the road without giving in to structural level.

- Vision technology - 2017 was the year when the first tyre was built entirely from recycled materials and 3D printing. It was found that there is no need for air to make it work; sensors that monitor the condition and notify the driver in case it is necessary to change the blades (3D printed too).

Michelin offers a wide range of technologies, being recognized in the market for its innovation centres. Apart from the innovations presented above, we can also mention: Inficoil technology, Powercoil technology, Regenion technology and RFID technology.

According to the official web site of Goodyear Romania, the latest technologies and innovations at the car tyre level are the following (Goodyear, 2020):

- SoundComfort Technology - The sources of noise in the car have different causes: speed, wind power, engine, but also tyres. The new tyres aim to reduce the noise inside the car by up to $50 \%$. A direct action is noticed in diminishing the resonance of the air cavity of the tyre and the unpleasant sound, overall offering a quieter driving. These tyres can be found in both winter and summer edition.

- SealTech - this technology supports drivers, if there is a puncture of the tyre up to $5 \mathrm{~mm}$, being able to automatically seal the tyre without having to stop the car. Thus, this solution is taken into consideration because there were no significant differences in performance between this type of tyre and the standard one.

- High and narrow - the "high" concept is based on a larger tyre diameter, implying both a smaller deformation and less heat in the tyre. "Narrow" means that the width section is smaller, having better aerodynamics, but also lower fuel/diesel consumption. Thus, better results were observed in the aquaplaning phenomenon.

Goodyear is not limited to the above technologies, having a larger range of products based on innovation such as the following technologies: Run on Flat, Active Corner Grip \& Active Breaking, Smart Wear, Silent Armor, TOP Indicator, Fuel Saving and Multi Control Ice.

Last but not least, Pirelli is well known in the automotive tyre industry, as the other companies presented above, but it differs from them by being the only company supplying tyres for Formula 1. Even though it invests a lot in developing such tyres, the company did not leave aside the standard tyres, having state-of-the-art technologies as it follows (Pirelli, 2020):

- Seal Inside technology - this tyre is notable for technology that helps drivers if they encounter problems with piercing or cutting rubber. Thus, 
Chicu, N., Prioteasa, A.L., Deaconu, A., (2020)

Current trends and perspectives in tyre industry

the tyre is built to be able to operate even if it loses pressure by avoiding possible accidents

- Noise Cancelling technology - this technology is applied to the tyre and it is designed to reduce the noise inside the car, having it mounted inside the polyurethane sponge tyre. Depending on the performance measured, the noise is reduced from 2 to 3 decibels.

According to the official Pirelli website, there are other types of innovations at the tyre industry level as follows: P Zero, Scorpion Zero and Cinturato technologies.

In conclusion, every company currently in the industry puts forward tyres and state-of-the-art solutions, trying to attract as many buyers as possible. It is certain that in order to remain in the market, the main word for the companies must be innovation. Even though innovation plays a key role in every company, we can state that the technology for the tyre industry was based on a few concepts, such as: run on flat, noise cancelling, reducing fuel, and eco-friendly designs.

\section{Methodology and empirical data}

The present research wants to answer to the 3 questions mentioned in the introduction. For this, we applied the following methodology: the first step consisted in researching information in the literature review, followed by researching the main technological advances that support the productivity increase in tyre industry, in the case of the 4 major players. Studying statistical reports proved to be useful when profiling the major players on this market. The second step consisted to brought up the attention of a number of specialists that were invited to take part to this research in a focus group, helping us to answer to the $2^{\text {nd }}$ research question. The focus group was formed by 4 people that are working in automotive industry, in different companies, in managing positions -2 of them have a work experience between 10-15 years and the other 2 have more than 20 years' work experience in the industry. These persons are 35-60 years old, they live in large cities and they have a bachelor degree. The theme of the focus group was based on the trends and perspective of the tyre industry, where the participants had to answer to 3 questions, the main interest was to discover/pointing out the factors that will increase the production of the tyre industry. The focus group worked for one hour, and they were interviewed via an online video conference due to restricted condition of Covid-19.

The second step consisted in using the SWOT analysis for the main 4 competitors in the tyre industry, thus figuring out the answer for question 3.

Without a doubt, the technological evolution makes its presence felt in all areas, including the tyre industry. In the same time, the development of this industry is based on the latest technologies, one noticing some trends within the big companies such as: tyres with systems to reduce fuel consumption, sound 
Chicu, N., Prioteasa, A.L., Deaconu, A., (2020)

Current trends and perspectives in tyre industry

absorbing technology tyres, tyres with technical characteristics that reduce plastic use, tyres with reducing pollution technologies, which contribute to creating a healthier environment.

As we presented above, each company tries to have its own technological contribution, managing to bring innovation to the forefront. Moreover, the effort of automotive tyre companies comes to support the production of electric cars, while also developing connections between the external elements of the car, such as tyres.

The word "connectivity" has become a basic principle for the automotive industry, being closely linked to all the peripheral elements of the car. Car manufacturers are not trying to sell a simple car, but one where they can provide mobility as a service (Mohagheghzadeh \& Svahn, 2016).

Now, you do not need to go to a mechanic to check your wheel pressure, it is enough to have an application and signal directly to your phone, if your tyres have a problem. Moreover, the proposed technological solutions bring to the fore plans and applications that show you real-time fuel consumption, depending on the driving mode of the drivers, showing the degree of tyre wear and what is the best sequence of time for changing the tyres. If we look in the past, all these solutions did not exist, and people had to discover all the issues related to car tyres all by themselves.

The answer to the $2^{\text {nd }}$ research question was based on the literature and with the help of the anwers gathered from the focus group. Thus, our efforts were concentrated to discover the main factors that will increase the production of the tyre industry. Our respondents stated out that these factors may vary from country to country, the trend being ascending and noticing a growing rate of tyres production, each year. Taking into consideration the evolution of the current tyre market, our respondents estimated an annual growth of 3-5\%, which is also confirmed by the literature. Thus, based on the information presented in the article, the tyre industry has increased on average by $3-3.5 \%$ and is expected to continue to grow in the future.

The second question addressed to the focus group referred to foreign competition in the automotive tyre industry. The respondents considered that China is the main threat, due to its production force in the automotive tyre industry, at low costs, thus gaining a competitive advantage, in contrast with its competitors. Our respondents also considered that consumers' preferences changed - they buy larger volumes, with cheaper prices and a poorer quality standard. So, considering that a tyre lifespan is 2 to 3 years, this is the reason why drivers need to buy new tyres or repurchased ones, this being the first growth factor of the tyre manufacturing industry. 
Chicu, N., Prioteasa, A.L., Deaconu, A., (2020)

Current trends and perspectives in tyre industry

The third question addresed to the focus group referred to the main factors that will help increase tyre production - the respondents stated that the first factor is the massive production of vehicles (electric, agricultural, passenger), the second one is cars with original manufactured equipment (OEM). All the participants underlined the third factor which refers to some European countries that demand drivers to have their cars equipped with winter tyres, which also contributes to the growth of the tyre industry. In conclusion, we may state that main factors of a growing productivity in the tyre manufacturing industry are present in Asian countries like China and India, in OEM car plants and in countries which demand mandatory winter tyres.

The answer for the $3^{\text {rd }}$ research question was based on the SWOT analysis performed on the following companies: Bridgestone, Michelin, Goodyear and Pirelli to reveal the risks, the weaknesses and the opportunities, which they may face in an unstable economic environment. The analysis aims to highlight the current threats for companies, what they face and what are the opportunities and strengths they have. Given the fluctuating economic environment, each company is trying to create its own strategy, in order to sell as many tyres as possible and to gain as much market share as possible. During the SWOT analysis, the common threats of the companies were highlighted.

\subsection{Main findings}

Performing a SWOT analysis proves to be useful when identifying such features strengths, weaknesses, opportunities and threats in the case of the leading positions in tyre manufacturing industry, thus a providing an overview image on a constant changing market.

The first SWOT analysis is targeted on Goodyear (Table 3) and the collected information is updated, in order to have a complete image on the company.

Undoubtedly, we can state that the main challenges for Goodyear company are the changing prices for raw materials and the cost fluctuations of the market. Even more, the company is facing a strong competition coming from China and it is expected that the new strategy of Goodyear will be concentrated on luxury tyres and on the production of motorcycle tyres.

Moreover, the efforts of the company are focused also on the proactive solutions offered to the big logistic companies in order to have a better visibility, on avoiding breakdowns, preventing accidents, minimising vehicle immobilisation and transmission of all data in real time on a server. All of these are made in order to assure the predictive steps needed for improvement, by increasing performance and reducing operating costs. 
Chicu, N., Prioteasa, A.L., Deaconu, A., (2020)

Current trends and perspectives in tyre industry

Table 3 SWOT analysis of Goodyear

Strengths:
- Align product portfolio that ensures high growth and automatically becomes profitable: Eagle F1 All Season, Wrangler SRA and Fuel Max;

- The products and services provided by Goodyear involve the creation of a strong and sustainable brand, based on innovation;

- The integration of all segments, starting from NASCAR to commercial tyres has a very good synchronization;

- The company is focused on the needs of the consumer, but is also understanding the needs and demands of each market and consequently developing individual tyres;

- The company focuses its efforts on new products such as the $17 \mathrm{~cm}$ premium segment;

- Association of the company with racing events such as NASCAR or Formula 1.

Opportunities:

- High potential for luxury tyres of category $17 \mathrm{~cm}$ or higher;

- Increased demand in emerging markets, with an increase in the auto and motorcycle market.

\section{Weaknesses:}

- Inventory control suffers due to cost fluctuations. This affects the prices and quality of the products and ultimately, the branding strategy;

- The large size of the company and economic instabilities around the world can lead to additional costs;

- The prices of the raw material used for the manufacture of the tyre increased due to the fluctuations of the oil prices; ultimately, this had a direct impact on the prices of the finished tyres.

\section{Threats:}

- Strong competition with companies in the sector: Bridgestone, Michelin, as well as local competitors from each regional market;

- Cost fluctuations due to volatile commodity market, costs of synthetic rubber, carbon black and chemical solvents create huge challenges for the company;

- Global medical issues, such as COVID-19 the production of tyres, by the possibility of closing the tyre plants.

Source: adaptation after SWOT analysis of Goodyear, 2019

The next analysis is made for Michelin company (Table 4). As we already know, Michelin company is ranked on the second position in the tyre industry, after Bridgestone company. Even though, Michelin is facing some challenges, being absent from the emerging markets and concentrating its production on the USA and European markets. This is not the only challenge, as the company produces premium tyres and thus it does not address to the small and middle classes

S sciendo Studia Universitatis "Vasile Goldis" Arad. Economics Series Vol 30 Special Issue 2/2020 
Chicu, N., Prioteasa, A.L., Deaconu, A., (2020)

Current trends and perspectives in tyre industry

customers. As for Goodyear, the company is threatened by the raw materials prices and is trying to develop its own materials and keep the production under control. The biggest strength of the company is based on the power of innovation, which means that every year tries to bring novelties on the market, by continuous development and research.

Table 4 SWOT analysis of Michelin

\section{Strengths:}

- Focusing on the characteristics of the car tyres, such as: resistance, durability, fuel reduction and noise reduction;

- Understanding the needs of all customers and meeting them;

- Focused on innovation, the company is heavily relying on research and development. Due to motorsport experiences, tyres have a higher endurance;

- Materials developed by the company, created after years of research, in order to make the finished productand not use pre-existing products;

- Green tyres - the company tries to reduce the carbon footprint as much as possible, by creating low-energy and sustainable tyres.

\section{Opportunities:}

- A growing demand for tyre replacement is predicted in the future, due to increased entry costs and prices for rubber and fuel;

- In emerging countries, such as China, India and Brazil, vehicle sales are expected to increase which will automatically lead to tyre demands and sales;

- The company's new focus on digital services, addressing applications such as tyre monitoring, GPS, data transfer.

\section{Weaknesses:}

- Michelin is not present in emerging markets, relying more on the European and the USA markets;

- Michelin tyres are premium quality, thus expensive, which is why Michelin is not a choice for middle and lower classes customers;

- Withdrawal from the market of the tyrewith sensors that could sense for perforations, which led to financial losses within the company.

Source: adaptation after SWOT analysis of Michelin Tyres, 2019 
Chicu, N., Prioteasa, A.L., Deaconu, A., (2020)

Current trends and perspectives in tyre industry

The next SWOT analysis is made for Bridgestone company (Table 5) and points out the following aspects: in terms of weaknesses, the company faces the same problems as the other direct competitors - unstable raw materials market and the dependence on natural rubber. Being the leader of the industry creates challenges every day and forces the company to be up to date with the market and changes that occur at the global level. Even if the company has a worldwide presence, the company faces risks of natural disasters, which will stop the production of tyres and reduce its volumes. The main advantage of this company is based on the strategy of execution, being recognized as the most efficient one at the global level. The analysis also reveals the fact that the company will benefit from the demand of passenger car tyres, by increasing their profit. Without a doubt, Bridgestone continues to invest money on research and development, in order to maintain a leading position.

Table 5 SWOT analysis of Bridgestone

\begin{tabular}{|c|c|}
\hline $\begin{array}{l}\text { Strength: } \\
\text { - Strong global presence and broad } \\
\text { product portfolio; } \\
\text { - Research and development is stimulated } \\
\text { and sustained to strengthen innovation } \\
\text { and increase productivity; } \\
\text { - Strong performance achieved in the tyre } \\
\text { segment by a strategy based on efficient } \\
\text { execution. }\end{array}$ & $\begin{array}{l}\text { Weaknesses: } \\
\text { - Increased costs with raw materials; } \\
\text { - Dependence on natural rubber from } \\
\text { S-E Asia. }\end{array}$ \\
\hline $\begin{array}{l}\text { Opportunities: } \\
\text { - Increased global demand for passenger } \\
\text { car tyres; } \\
\text { - Increased tyre segment for hybrid and } \\
\text { electric cars. }\end{array}$ & $\begin{array}{l}\text { Threats: } \\
\text { - Strong competition for maintaining } \\
\text { the first place in the industry; } \\
\text { - Risks of natural disasters. }\end{array}$ \\
\hline
\end{tabular}

Source: adaptation after Bidgestone SWOT and PESTLE Analysis, 2019

The last SWOT analysis is on the Italian company - Pirelli. In this context, we observed that the main challenges for this company are the following: because Pirelli is trying to maintain the position in the market, it becomes very difficult to produce large volumes, by focusing on consumer tyres, only. Thus, the competitors can take advantage of this weakness and overcome the margins of profit. As mentioned above, Pirelli also faces the rising prices of raw materials prices, having difficulties on adopting the right strategy, even though the biggest strength of the company is recognized worldwide, being the only supplier for Formula 1 and providing the best motor sports technologies. Another opportunity that Pirelli should take advantage of is represented by the market growth in Brazil, India and 
Chicu, N., Prioteasa, A.L., Deaconu, A., (2020)

Current trends and perspectives in tyre industry

China. Thus, in the next period, Pirelli should concentrate its efforts on the strategy of satisfying the needs of the customers from those countries, by selling as much as possible.

Table 6 SWOT analysis of Pirelli

\section{Strengths:}

- Focus is only on consumer segments, producing tyres for motorcycles, scooters, bicycles and passenger cars;

- The focus is on $18 \mathrm{~cm}$ tyres, creating high performance premium tyres with specific characteristics;

- Exclusive supplier for SBk and Formula 1 , the company being an expert in motor sports technology.

\section{Weaknesses:}

- The company has reorganized itself, eliminating the focus on industrial tyres, choosing to focus only on consumer tyres;

- The production of large volumes becomes a challenge for the company because of the strong competition in the sector and reduced sales;

- Facing problems in the company's operations proves to be costly;

- The company's initiatives to generate added value had additional costs.

\section{Opportunities:}

- Market growth in China, India and Brazil, with a growth of $9 \%$ between 2015-2021;

- An increase in the tyre need is expected to meet the needs of adhesion and safety.

\section{Threats:}

- Competition with major companies in the field, such as Michelin, Bridgestone, Goodyear;

- The price of tyres is in jeopardy, due to high costs of raw materials, technology and innovation;

- COVID-19 virus threatened all the factories of the company, being able to cause a disruption.

Source: adaptation after SWOT analysis of Pirelli Tyres, 2019

Summarizing, these SWOTS reveal interesting information. In terms of strengths, we may state that these companies share features like:

- research for innovative solutions meant to increase productivity, reduce pollution and create new types of products - furthermore, these companies invest in their own research facilities;

- two of these companies, are official suppliers in sport competitions Goodyear is the official supplier for NASCAR and NHRA, while Pirelli is the exclusive supplier for SBk and Formula 1;

- all companies are deeply committed to satisfy the customers' needs. 
Chicu, N., Prioteasa, A.L., Deaconu, A., (2020)

Current trends and perspectives in tyre industry

In contrast, in terms of strengths, Pirelli focuses its products on consumer products, especially the $18 \mathrm{~cm}$ tyres, while Goodyear tries to reach the premium customer segment, selling its $17 \mathrm{~cm}$ tyres.

In terms of weaknesses, we noticed the following aspects:

- all companies share one feature - high prices of raw materials, which leads to higher costs of the finished products;

- Goodyear faces difficulties, because of its large size, while Michelin does not sell its products on the emerging markets and Pirelli has difficulties in producing large volumes.

Considering opportunities, we noted that:

- all 4 companies try to reach the emerging countries, as an alternative of expanding their market;

- Michelin makes use of the technological progress, such as digital services, various applications that monitor the state of tyres and their degree of wear or assistance in case of need, while Bridgestone focuses on tyres for hybrid and electric cars.

Looking at threats, we observed that all 4 companies face a strong competition, especially with Asian countries, followed by price instability for raw materials, which has effects on the final costs. The latest threat refers to the risk of global pandemics, which leads to workers' potential mass infection, resulting in closing production facilities.

At the global level there are some common threats for all the companies that produce car tyres and contribute actively to the growth of the industry. However, the most important ones have been observed for the raw material prices that are in a continuous expansion, for the strong competitors coming from Asian countries and as well as for the medical factors that can affect the industry by closing the factories (e.g. COVID-19 virus).

\section{Conclusions}

In conclusion, the tyre industry is permanently developing, with a noticeable growth in the recent years. The predictions for this industry are that it will increase in the next years, having as determinants the evolution of the automotive industry, and more precisely, building new cars and the opening of new markets in Asian countries, such as China. We include in the automotive industry the building of new electric cars that will increase this industry, coming with original equipped manufacturing (OEM).

These companies conducted extensive research, which led to innovation - new types of tyres, that are safer in use; technologies that produce tyres with significant smaller carbon footprint. It can be easily seen that these companies no longer sell only a single product, but instead, they sell an integrated service, that brings 
Chicu, N., Prioteasa, A.L., Deaconu, A., (2020)

Current trends and perspectives in tyre industry

multiple benefits to customers, such as: real-time checking of the pressure on the wheels, how worn the tyres are, when they need to be changed.

At the level of car tyres, trends are focused on key concepts, such as: the use in a smaller proportion of the black carbon, that, on one hand, contributes to the reduction of gas emissions and, on the other, helps the environment by reducing pollution; the use of silica in a larger proportion in the tyre components helps to improve the rolling performance, which leads to a higher resistance of the tyres, in case they are perforated. Another trend that can be seen in the industry is represented by radial tyres, which help reduce fuel consumption, while also reducing shocks with objects found on the street. Moreover, if the noise is produced by tyres, which was a problem for the driver, now, with the noise cancelling technology, this does not happen anymore. Basically, the tyre noise is diminished, giving the driver the same performance as the classic tyres.

Increasing productivity is based on the use of new technologies which leads to producing higher quality tyres, which are more reliable.

As a final remark, we can state that the tyre industry is in a period of change, which will develop more and more, coming to the support of final consumers.

\section{Acknowledgements}

The authors would like to thank to the project members and to the anonymous reviewers and editor for their valuable contribution.

\section{Funding}

This work was co-financed from the European Social Fund through Operational Programme Human Capital 2014-2020, project number POCU/380/6/13/125015 "Development of entrepreneurial skills for doctoral students and postdoctoral researchers in the field of economic sciences".

\section{Author Contributions}

The authors created the study and they are responsible for the design and development of the data analysed and for the data interpretation.

\section{Disclosure Statement}

The authors do not have any competing financial, professional or personal interests from other parties.

\section{References}

1. A global footprint, (2020), Retrieved from:

https://www.michelin.com/en/michelin-group/about-us/michelin-global/, Accessed on 8 January 2020

52 Sciendo Studia Universitatis "Vasile Goldis" Arad. Economics Series Vol 30 Special Issue 2/2020 ISSN: 1584-2339; (online) ISSN: 2285 - 3065

Web: publicatii.uvvg.ro/index.php/studiaeconomia. Pages $36-56$ 
Chicu, N., Prioteasa, A.L., Deaconu, A., (2020)

Current trends and perspectives in tyre industry

2. Anvelope radiale vs. Anvelope diagonale, (2019), Retrieved from:

https://agro.michelin.ro/ro/Utiliza-i-in-mod-corect anvelopele/Anvelope-radiale-

vs.-anvelope-diagonale, Accessed on 7 January 2020

3. At a glance - Global, (2019), Retrieved from:

https://www.goodyear.eu/corporate_emea/our-company/at-a-glance.jsp, Accessed on 8 January 2020

4. Bhasin, H., (2019a), SWOT analysis of Goodyear, Retrieved from:

https://www.marketing91.com/swot-analysis-goodyear-tyres/, Accessed on 10

January 2020

5. Bhasin, H., (2019b), SWOT analysis of Michelin Tyres, Retrieved from:

https://www.marketing91.com/swot-analysis-michelin-tyres/, Accessed on 10 January 2020

6. Bhasin, H., (2019c), SWOT analysis of Pirelli Tyres, Retrieved from:

https://www.marketing91.com/swot-analysis-pirelli-tyres/, Accessed on 9 January

2020

7. Bridgestone DriveGuard, Retrieved from:

https://www.bridgestone.co.uk/driveguard/?referrer=https\%3A\%2F\%2Fwww.goog le.com $\% 2 \mathrm{~F}$, Accessed on 8 January 2020

8. Bridgestone introduces Enliten, a new lightweight tyre technology, Retrieved from:

https://www.bridgestonenewsroom.eu/brandportal/bridgestonepr/default/news-

detail/767?lang=eu, Accessed on 9 January 2020

9. Bridgestone SWOT and PESTLE Analysis, (2019), Retrieved from:

https://www.swotandpestle.com/bridgestone/ Accessed on 9 January 2020

10. Cohen, B., Kietzmann, J., (2014), Ride on! Mobility business models for the sharing economy, Organization \& Environment, 27(3), 279-296

11. Cum au evoluat anvelopele?, (2011), Retrieved from:

https://www.anvelope.ro/blog/cum-au-evoluat-anvelopele.htm, Accessed on: 10 January 2020

12. EP422, Retrieved from: https://www.bridgestonetire.com/tire/ecopia-ep422-eco Accessed on 8 January 2020

13. Five trends transforming the Automotive Industry - PWC report 2018, (2018), Retrieved from:

https://www.pwc.at/de/publikationen/branchen-und-wirtschaftsstudien/eascy-fivetrends-transforming-the-automotive-industry_2018.pdf. Accessed on 5 February 2020

14. Frent, P., (2010), World Tyre Manufacturers. Market Analysis - 2010-2015 Trends - Corporate Strategies. Retrieved from: 
Chicu, N., Prioteasa, A.L., Deaconu, A., (2020)

Current trends and perspectives in tyre industry

https://ro.scribd.com/document/229316897/tyrefbclid=IwAR1oPZjjDSnGUN0hs7

SGENNedclqWZGm3toPilE1G4nBEcbLptrOpLaTYBw, Accessed on 20 January 2020

15. Gao, P., Kaas, H.W., Mohr, D., Wee, D., (2016), Automotive revolution Perspective towards 2030. How the convergence of disruptive technology-driven trends could transform the auto industry, Retrieved from:

https://www.mckinsey.com/ /media/mckinsey/industries/automotive\%20and\%20a ssembly/our\%20insights/disruptive $\% 20$ trends $\% 20$ that $\% 20$ will\%20transform $\% 20$ th e\%20auto\%20industry/auto\%202030\%20report\%20jan\%202016.ashx, Accessed on 20 January 2020

16. Global Network, (2020), Retrieved from:

https://www.hankooktire.com/global/about-hankook-tire/company/globalnetwork.html, Accessed on 8 January 2020

17. Guga, S.., (2018), Industria auto, incotro? Tendințe globale, perspective periferice, Retrieved from: http://library.fes.de/pdf-files/bueros/bukarest/15195.pdf Accessed on 10 January 2020

18. Harris, G.T., (1993). The Post-Capitalist Executive: An Interview with Peter F. Drucker, Harvard Business Review', May-June 1993, Retrieved from:

https://hbr.org/1993/05/the-post-capitalist-executive-an-interview-with-peter-fdrucker, Accessed on 15 December 2019

19. Innovation, (2019), Retrieved from: https://www.pirelli.com/global/enww/articles/tag/innovation, Accessed on 10 January 2020

20. Location worldwide, (2020), Retrieved from:

https://www.continental.com/en/company/continental-locations-worldwide, Accessed on 8 January 2020

21. Michelin 2017 Annual report, (2018), Retrieved from:

https://www.michelin.com/en/finance/regulated-information/annual-report/,

Accessed on 15 February 2020

22. Michelin, GM take the air out of tires for passenger vehicles, Retrieved from: https://michelinmedia.com/michelin-uptis/, Accessed on 9 January 2020

23. Mohagheghzadeh, A., Svahn, F., (2016), Transforming organizational resource into platform boundary resources, Twenty-fourth European conference on information systems (ECIS), Vol. 2016. İstanbul, Turkey, 1-14

24. Moving innovation that cares - Annual Report 2017, (2017), Retrieved from: https://www.etrma.org/wp-content/uploads/2019/09/20170905-etrma-annualreport-2016-17-final.pdf, Accessed on 15 February 2020

25. Noua inovație Pirelli: Noise Cancelling System, (2013), Retrieved from: https://www.anvelope.ro/blog/pirelli-inovatie-reducere-zgomot.htm, Accessed on 15 January 2020

54 Sciendo Studia Universitatis "Vasile Goldis" Arad. Economics Series Vol 30 Special Issue 2/2020 ISSN: 1584-2339; (online) ISSN: 2285 - 3065

Web: publicatii.uvvg.ro/index.php/studiaeconomia. Pages $36-56$ 
Chicu, N., Prioteasa, A.L., Deaconu, A., (2020)

Current trends and perspectives in tyre industry

26. Ordonanţa pentru aprobarea unor reglementări privind creşterea siguranţei rutiere şi destinația sumelor încasate de către personalul împuternicit cu atribuţii de inspecţie şi control în urma aplicării sancţiunilor contravenţionale specifice activităţii de transport rutier, (2011), Retrieved from:

https://www.arr.ro/Files/uploads/25-5.pdf Accessed on 15 January 2020

27. Pirelli extended mobility, Retrieved from: https://www.pirelli.com/tyres/enww/car/total-mobility, Accessed on 8 January 2020

28. Pirelli in the world, (2019), Retrieved from:

https://corporate.pirelli.com/corporate/en-ww/aboutus/worldwide-presence,

Accessed on 8 January 2020

29. Pirelli noise cancelling system, Retrieved from:

https://www.pirelli.com/tyres/en-ww/car/pncs-technology, Accessed on 8 January 2020

30. Seal Inside ${ }^{\mathrm{TM}}$ : puncture resistant,(2015), Retrieved from:

https://www.pirelli.com/tyre/ww/en/news/2015/06/10/pirellis-new-solution-for-

mobility-the-seal-inside\%E2\%84\%A2-technology/, Accessed on 8 January 2020

31. SoundComfort Technology: Uneori mai puțin înseamnă mai mult, Retrieved from:https://www.goodyear.eu/ro_ro/consumer/why-goodyear/soundcomfort-

technology.html, Accessed on 10 January 2020

32. Stoian, F. Perspectivele de creștere pe termen scurt și mediu ale pieței mondiale a anvelopelor, Retrieved from:

http://www.nos.iem.ro/bitstream/handle/123456789/989/436-731-1-

PB.pdf?sequence $=1 \&$ is Allowed $=\mathrm{y}_{2}$ Accessed on 1 February 2020

33. Summary of Bridgestone's Manufacturing Plants (As of April 1, 2019), (2019),

Retrieved from: https://www.bridgestone.com/corporate/locations/index.html, Accessed on 8 January 2020

34. Svahn, F., Mathiassen, L., Lindgren, R., (2017), Embracing digital innovation in incumbent firms: How Volvo cars managed competing concerns, MIS Quarterly, 41(1), 239-254

35. Tehnologia și inovația, (2019), Retrieved from:

https://www.goodyear.eu/ro_ro/consumer/why-goodyear/technology-and-

innovation.html, Accessed on 8 January 2020

36. Tehnologiile folosite, (2019), Retrieved from:

https://camion.michelin.ro/Know-how/Tehnologiile, Accessed on 8 January 2020

37. The technology of MICHELIN® radial tires, Retrieved from:

https://www.michelinearthmover.com/eng_ca/Welcome/Tires/Why-choose-

MICHELIN/The-technology-of-MICHELIN-R-radial-tires, Accessed on 9 January 2020

38. Tyres, (2019), Retrieved from:

https://www.bridgestone.com/products/index.html, Accessed on 08 January 2020

$S$ sciendo Studia Universitatis "Vasile Goldis" Arad. Economics Series Vol 30 Special Issue 2/2020

ISSN: 1584-2339; (online) ISSN: $2285-3065$ 
Chicu, N., Prioteasa, A.L., Deaconu, A., (2020)

Current trends and perspectives in tyre industry

39. VISION concept: An avant-garde tire, Retrieved from:

https://www.michelin.com/en/innovation/innovation-strategy/vision-concept/, Accessed on 9 January 2020

40. Winter tyres in Europe, (2011), Retrieved from:

https://www.oponeo.co.uk/blog/winter-tyres-in-europe, Accessed on 10 January 2020 